\title{
ANALYSIS CONCENTRATION OF NITRATE, PHOSPHATE, SILICATE AND RELATIONSHIP WITH DIATOM ABUDANCE IN WATERS TANJUNG TIRAM DISTRCTS BATU BARA REGENCY OF NORTH SUMATERA PROVINCE
}

\author{
Rahmad Hidayat $^{1}$, Syahril Nedi ${ }^{2}$ dan Irvina Nurrachmi ${ }^{2}$ \\ ${ }^{1}$ Student of The Faculty of Fisheries And Marine Science University of Riau, Pekanbaru \\ ${ }^{2}$ Lecturer at the Faculty Of Fisheries And Marine Science University Riau, Pekanbaru \\ *rahmadhidayat9898@gmail.com
}

\begin{abstract}
Input of nutrients into the waters from various human activities (residential, agriculture and industry) has the potential to cause changes in the physical, chemical and biological conditions of the waters. The study aims to determine the relationship of concentrations of nitrate, phosphate and silicate with the abundance of diatoms in the Tanjung Tiram waters. The method used is the survey method, the determination of the location of sampling is done by purposive sampling, data analysis (multiple regression). Based in the results of laboratory analysis nitrate concentrations ranged from $0,0819-0,1167$ $\mathrm{mg} / \mathrm{l}$, the phosphate concentration ranged from $0,1002-0,1526 \mathrm{mg} / \mathrm{l}$, and silicate concentration ranged from $0,04447-0,5418 \mathrm{mg} / \mathrm{l}$. The abundance of diatoms in Tanjung Tiram waters ranged from 156,9 - 302,8 ind/l. The results of statistical analysis of the relationship of nitrate, phosphate and silicate with the abundance of diatoms are expressed in terms of equation $\mathrm{Y}=350,906-58,065_{\text {Nitrate }}-2644,624_{\text {phosphate }}+440,363_{\text {Silicate. }}$ This statement explains the concentration of nitrate, phosphate related negative (-) to the abundance of diatoms and silicate positive $(+)$ related to the abundance of diatom. This condition shows that the nutrient concentration in these waters is relatively high so that it affects the abundance of diatoms.
\end{abstract}

Keyword: Diatom, Nitrate, Phosphate, Silicate, Tanjung Tiram

\section{PENDAHULUAN}

Fitoplankton termasuk produsen primer yang berperan dalam rantai makanan karena memberi kontribusi yang besar terhadap ekosistem perairan. Produksi bahan organik dari unsur anorganik yang dilakukan oleh fitoplankton dengan melalui proses fotosintesis yang merupakan sumber energi utama dalam ekosistem. Diatom merupakan fitoplankton dengan jumlah spesies terbesar di perairan laut dibandingkan dengan mikroalga lainnya (Nengsih et al., 2015).

Kelimpahan diatom dapat dijadikan sebagai bioindikator dalam menentukan kesuburan suatu perairan yang dipengaruhi oleh faktor fisika (cahaya, arus) dan kimia laut (ketersediaan nutrien nitrat, fosfat dan silikat) perbedaan parameter fisika dan kimia tersebut secara langsung merupakan penyebab bervariasinya diatom di beberapa tempat pada perairan laut. Diatom memiliki batas toleransi tertentu terhadap faktorfaktor ini, sehingga akan membentuk struktur komunitas diatom yang berbeda. Kombinasi pengaruh antara faktor-faktor tersebut dan kelimpahan diatom menjadikan komunitas dan dominasi pada setiap perairan tidak sama sehingga dapat dijadikan sebagai indikator biologis perairan (Nontji, 2008). 
Nitrat adalah bentuk utama nitrogen di perairan dan merupakan nutrien utama yang dibutuhkan bagi pertumbuhan tanaman dan algae. Nitrat sangat mudah larut dalam air dan bersifat stabil. Fosfat adalah bentuk fosfor yang dapat dimanfaatkan oleh tumbuhan dan merupakan unsur esensial bagi tumbuhan tingkat tinggi dan algae sehingga dapat mempengaruhi tingkat produktivitas perairan. Silikat merupakan nutrien yang sangat dibutuhkan oleh diatom untuk pembentukan dinding sel, ketersediaan silikat yang cukup dalam perairan dapat meningkatkan pertumbuhan diatom.

Kawasan pesisir juga telah menjadi pusat-pusat industri, yang sering kali membuang limbah ke laut. Di samping kegiatan pelabuhan dan eksploitasi sumberdaya tambang berpotensi mencemari lingkungannya, sehingga pada umumnya kondisi perairan di kota-kota pesisir mempunyai tingkat pencemaran yang tinggi.Tanjung Tiram terletak di Kabupaten Batu Bara Provinsi Sumatera Utara yang merupakan perairan semi terbuka dan masih mendapat pengaruh sifat laut serta menerima pemasukan yang berasal dari daratan. Perairan Tanjung Tiram ini merupakan perairan yang mempunyai fungsi ekonomis, karena ini merupakan lahan kehidupan bagi penduduk sekitar, mulai dari kegiatan transfortasi laut, nelayan sampai pelaku bisnis.

Terbatasnya informasi yang diperoleh tentang kondisi perairan Tanjung
Tiram dengan berbagai aktivitas antropogeniknya. Berdasarkan uraian diatas perlu dilakukan penelitian mengenai "Analisis Konsentrasi Nitrat, Fosfat dan Silikat Serta Hubungannya dengan Kelimpahan Diatom di Perairan Tanjung Tiram Kabupaten Batu Bara Provinsi Sumatera Utara".

Tujuan Penelitian ini adalah untuk mengetahui kondisi perairan, jenis diatom, besarnya konsentrasi nitrat, fosfat dan silikat serta mengetahui hubungan kelimpahan diatom dengan konsentrasi nitrat, fosfat dan silikat di perairan Tanjung Tiram.

\section{METODE PENELITIAN}

Penelitian ini telah dilaksanakan pada bulan Agustus 2018 yang bertempatkan di sekitar perairan Tanjung Tiram, Kabupaten Batu Bara, Provinsi Sumatera Utara. Analisis sampel diatom dilakukan di Laboratorium Biologi Laut dan analisis nitrat, fosfat dan silikat dilakukan di Laboratorium Kimia Laut, Jurusan Ilmu Kelautan Fakultas Perikanan dan Kelautan Universitas Riau.

Pengambilan sampel di perairan Tanjung Tiram dilakukan pada saat air laut pasang dan dilakukan dengan cara purposive sampling berdasarkan karakteristik kawasan dan lokasi pengamatan yang berbeda, daerah penelitian dibagi atas empat stasiun dengan jarak masing-masing 200 - 250 (Gambar 1). 


\section{PETA LOKASI PENELITIAN}

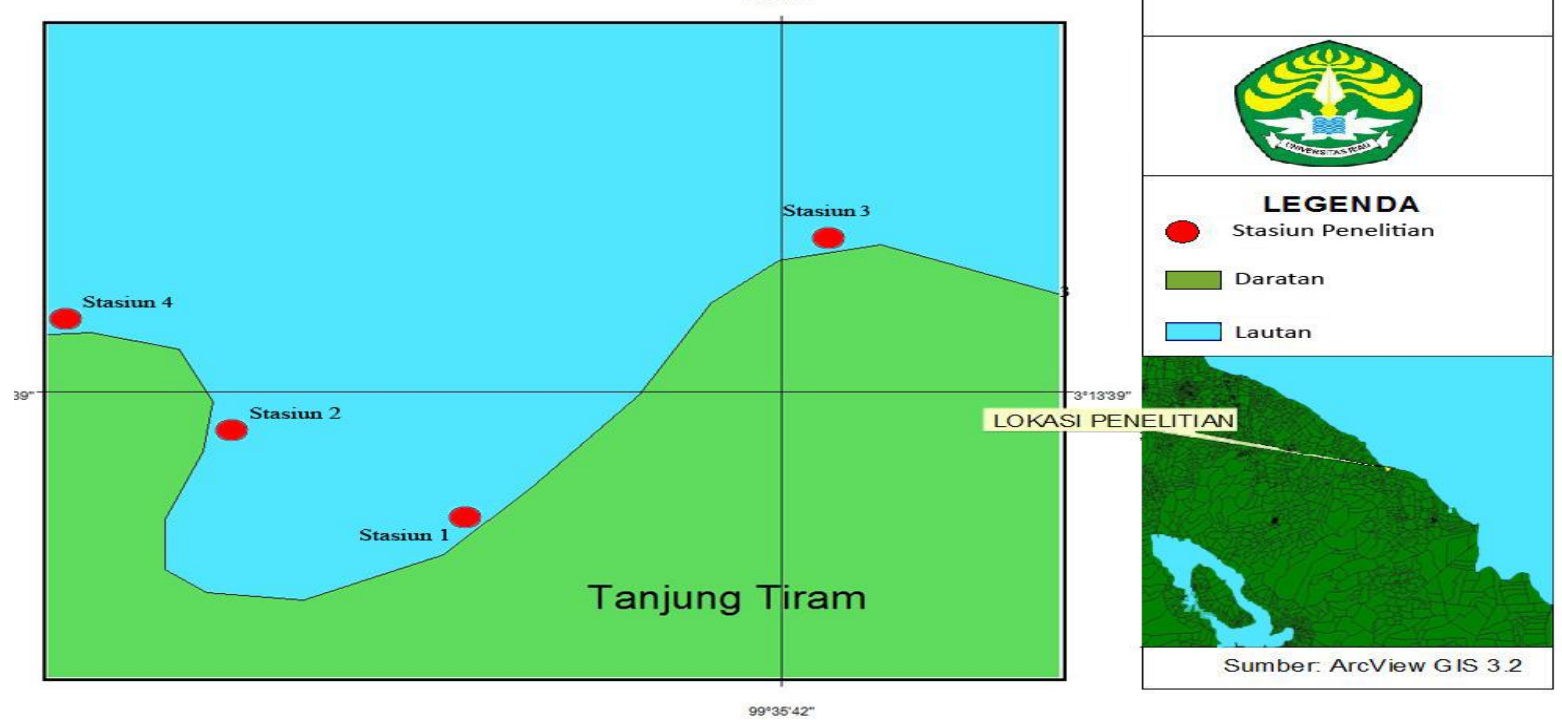

Gambar 1. Petas Stasiun dan Titik Sampling Penelitian

a. Stasiun 1 berada di sekitar pemukiman masyarakat.

b. Stasiun 2 berada di sekitar sekitar pelabuhan Tanjung Tiram.

c. Stasiun 3 terletak di sekitar kawasan hutan mangrove.

d. Stasiun 4 berada di sekitar kawasan dekat dengan industri pengolahan ikan.

Pengambilansampelair untuk analisis konsentrasi nitrat, fosfat dan silikat yaitu dengan menggunakan botol sampel. Sampel air diambil dipermukaan sebanyak $300 \mathrm{ml}$ pada saat air laut pasang menggunakan kapal motor, dan pada sampel nitrat diberi pengawet dengan menambahkan larutan asam sulfat pekat sebanyak 2 tetes. Lalu, botol-botol tersebut dibungkus menggunakan aluminium foil selanjutnya diberi label dan dimasukkan ke dalam ice box untuk analisis di laboratorium.

Sampel diatom diambil pada saat air laut pasang bersamaan dengan pengambilan sampel nitrat, fosfat dan silikat pada daerah permukaan sebanyak 100 liter menggunakan ember berukuran 10 liter yang sudah di standarisasi terlebih dahulu, kemudian disaring menggunakan plankton net No. 25. Hasil penyaringan sebanyak $125 \mathrm{ml}$ dimasukkan ke dalam botol sampel dan diberi pengawet berupa lugol 4\% sebanyak 4 tetes, selanjutnya diberi label dan diamati di laboratorium.

Pengukuran parameter kualitas perairan pada penelitian diukur langsung di lapangan pada saat air laut pasang sebanyak titik sampling, pengambilannya bersamaan dengan pengambilan sampel nitrat, fosfat, silikat dan diatom. Parameter yang diukur yaitu salinitas, suhu, kecepatan arus, kecerahan, oksigen terlarut dan $\mathrm{pH}$.

Pengamatan diatom dilakukan dengan cara meneteskan air sampel ke objek glass dengan metode sapuan dengan perbesaran $10 \quad \mathrm{x} \quad 10$ menggunakan mikroskop Olympus CX. Selanjutnya jenis 
diatom yang terlihat diidentifikasi berpedoman pada buku Thomas (1996). Kelimpahan diatom dihitung dengan merujuk pada rumus Fachrul (2007) dengan rumus:

Dimana :

$$
\mathrm{N}=\mathrm{n} \times \frac{V r}{V o} \times \frac{1}{V s}
$$

$\mathrm{N}=$ Jumlah ind per liter

$\mathrm{n}=$ Jumlah ind per liter

$\mathrm{V}_{\mathrm{r}}=$ Volume air tersaring $(125 \mathrm{ml})$

$\mathrm{V}_{\mathrm{o}}=$ Volume air yang diamati $(0,06 \mathrm{ml})$

$\mathrm{V}_{\mathrm{s}}=$ Volume air yang disaring $(100 \mathrm{ml})$

Analisis nitrat dilakukan dengan menggunakan metode Brucine. Pengukuran nitrat dilakukan dengan cara menyaring air sampel sebanyak $15 \mathrm{ml}$ dengan menggunakan whatman paper No. 42 dan vaccum pump sebagai alat penghisap, kemudian ditambahkan larutan EDTA sebanyak 4 tetes lalu disaring dengan menggunakan colom $\mathrm{Cd}$, kemudian ditambahkan dengan larutan naptil 10 tetes dan larutan sulfanilamide 10 tetes, dilihat perubahan warna dari bening menjadi warna merah muda, dikocok dan diukur dengan menggunakan spectrophotometer dengan panjang gelombang $543 \mathrm{~nm}$.

Analisis fosfat dilakukan dengan cara menyaring air sampel sebanyak $15 \mathrm{ml}$ dengan menggunakan whatman paper No. 42 dan vaccum pump sebagai alat penghisap, kemudian ditambahkan larutan amonium molibdat sebanyak 10 tetes dan ditambahkan dengan $\mathrm{SnCl} 2$ sebanyak 3 tetes, dilihat perubahan warna dari bening menjadi warna biru dan diukur dengan menggunakan spectrophotometer dengan panjang gelombang $490 \mathrm{~nm}$.

Analisis silikat dilakukan dengan cara menyaring air sampel sebanyak $15 \mathrm{ml}$ dengan menggunakan whatman paper No. 42 dan vaccum pump sebagai alat penghisap, kemudian ditambah larutan $\mathrm{HCl}$ sebanyak 5 tetes dan ditambah larutan ammonium molibdate sebanyak 10 tetes, diamkan selama 10 menit kemudian ditambah 10 tetes asam oksalat dan diamkan selama 10 menit lihat perubahan dari warna bening menjadi kuning dan diukur dengan menggunakan spektofotometer pada panjang gelombang $410 \mathrm{~nm}$.

Analisis sidik ragam atau anova digunakan untuk mengetahui apakah terdapat perbedaan distribusi terhadap parameter-parameter yang diukur antar stasiun. Jika hasil analisis sidik ragam memperlihatkan perbedaan yang nyata, maka dilanjutkan dengan uji t-Tukey untuk mengetahui perbedaan tersebut.

Analisis regresi linier berganda digunakan untuk mengetahui ada atau tidaknya hubungan konsentrasi nitrat, fosfat dan silikat dengan kelimpahan diatom. Menurut Hidayatet al. (2009), analisis regresi linear berganda ini digunakan untuk memprediksi hubungan variable bebas terhadap variabel terikat dengan tujuan untuk melihat ada atau tidaknya hubungan diantara ketiga variabel tersebut. Kemudian bagaimana arah hubungannya dan seberapa kuatkah hubungan tersebut, berikut persamaan regresinya :

$$
\mathrm{Y}=\mathrm{a}+\mathrm{bx}_{1}+\mathrm{bx}_{2}+\mathrm{bx}_{3}
$$

Dimana :

$\mathrm{Y} \quad=$ Kelimpahan diatom (ind/l)

A dan $\mathrm{b}=$ konstanta dan koefisiensi regresi

$\mathrm{X}_{1} \quad=$ Konsentrasi Nitrat $(\mathrm{mg} / \mathrm{l})$

$\mathrm{X}_{2} \quad=$ Konsentrasi Fosfat $(\mathrm{mg} / \mathrm{l})$

$\mathrm{X}_{3}=$ Konsentrasi Silikat $(\mathrm{mg} / \mathrm{l})$

\section{HASIL DAN PEMBAHASAN}

\section{Kondisi Umum Lokasi Penelitian}

Secara hidrologi wilaya sungai terbesar yang terdapat di Kabupaten Batu Bara adalah Wilayah Sungai Bah Bolon dan sungai-sungai kecil lainnya yang mengalir ke pantai timur. Sungai-sungai ini 
merupakan sumber pengairan ke persawahan dan perkebunan. Sungaisungai di Kabupaten Batu Bara sebagian besar berhulu di pegunungan bukit barisan yang terdapat di Kabupaten Simalungun. Kondisi ini mengakibatkan fluktuasi air sungai sangat di pengaruhi oleh kondisi penggunaan lahan pada Daerah Aliran Sungai (DAS) bagian hulu.

Perairan Tanjung Tiram yang terletak di pantai timur Kabupaten Batu Bara merupakan daerah dimana aktivitas penduduknya langsung berhubungan dengan laut, seperti kegiatan pelabuhan dan buang limbah rumah tangga serta kegiatan darat seperti penggunaan lahan. Wilaya pesisir Tanjung Tiram terdiri dari 1 industri kecil dan 156 industri rumah tangga, serta dikenal dengan kawasan pariwisata dan terdapat 1 pelabuhan penyeberangan antar pulau, yaitu pulau pandang dan salah nama. Jenis penggunaan lahan dominan di Kabupaten Batu Bara adalah untuk budidaya komoditi perkebunan, terutama perusahan perkebunan Negara (BUMN) dan swasta nasional mencapai $49,61 \%$ dari total luas wilayahnya dan untuk perkebunan rakyat mencapai 21,35\%. (BPS Kabupaten Batu Bara, 2017).

\section{Parameter Kualitas Perairan}

Hasil pengukuran parameter kualitas perairan pada setiap stasiun penelitian dapat dilihat pada Tabel 1 .

Tabel 1. Parameter Kualitas Perairan

\begin{tabular}{lccccc}
\hline \multicolumn{1}{c}{$\begin{array}{c}\text { Parameter Kualitas } \\
\text { Perairan }\end{array}$} & Satuan & \multicolumn{4}{c}{ Stasiun } \\
\cline { 3 - 6 } & & I & II & III & IV \\
\hline $\mathrm{pH}$ & & 7 & 7 & 6 & 7 \\
Suhu & ${ }^{0} \mathrm{C}$ & 28 & 28 & 29 & 29 \\
Salinitas & $\mathrm{ppt}$ & 27 & 26 & 27 & 27 \\
Kecepatan Arus & $\mathrm{m} / \mathrm{det}$ & 0,2 & 0,19 & 0,2 & 0,2 \\
Kecerahan & $\mathrm{M}$ & 0,4 & 0,4 & 0,4 & 0,5 \\
Oksigen Terlarut & $\mathrm{mg} / \mathrm{l}$ & 4,56 & 5,22 & 5,6 & 6 \\
\hline
\end{tabular}

Dari Tabel 1 diketahui bahwa $\mathrm{pH}$ di perairan Tanjung Tiram berkisar antara $6-7$, suhu berkisar antara antara $28-29$ 0C, salinitas berkisar antara $26-27 \mathrm{ppt}$, kecepatan arus berkisar antara 0,19-0,20 $\mathrm{m} /$ det, kecerahan berkisar antara 0,4 - 0,5 $m$ dan oksigen terlarut berkisar antara 4,56 $-6 \mathrm{mg} / \mathrm{l}$.

\section{Konsentrasi Nitrat, Fosfat dan Silikat di Perairan Tanjung Tiram}

Zat hara merupakan zat-zat yang diperlukan dan mempunyai pengaruh proses dan perkembangan hidup organisme seperti fitoplankton, unsur hara yang diukur pada penelitian ini adalah nitrat, fosfat dan silikat, untuk melihat nilai konsentrasi nitrat, fosfat dan silikat antar stasiun dapat dilihat pada Gambar2. 


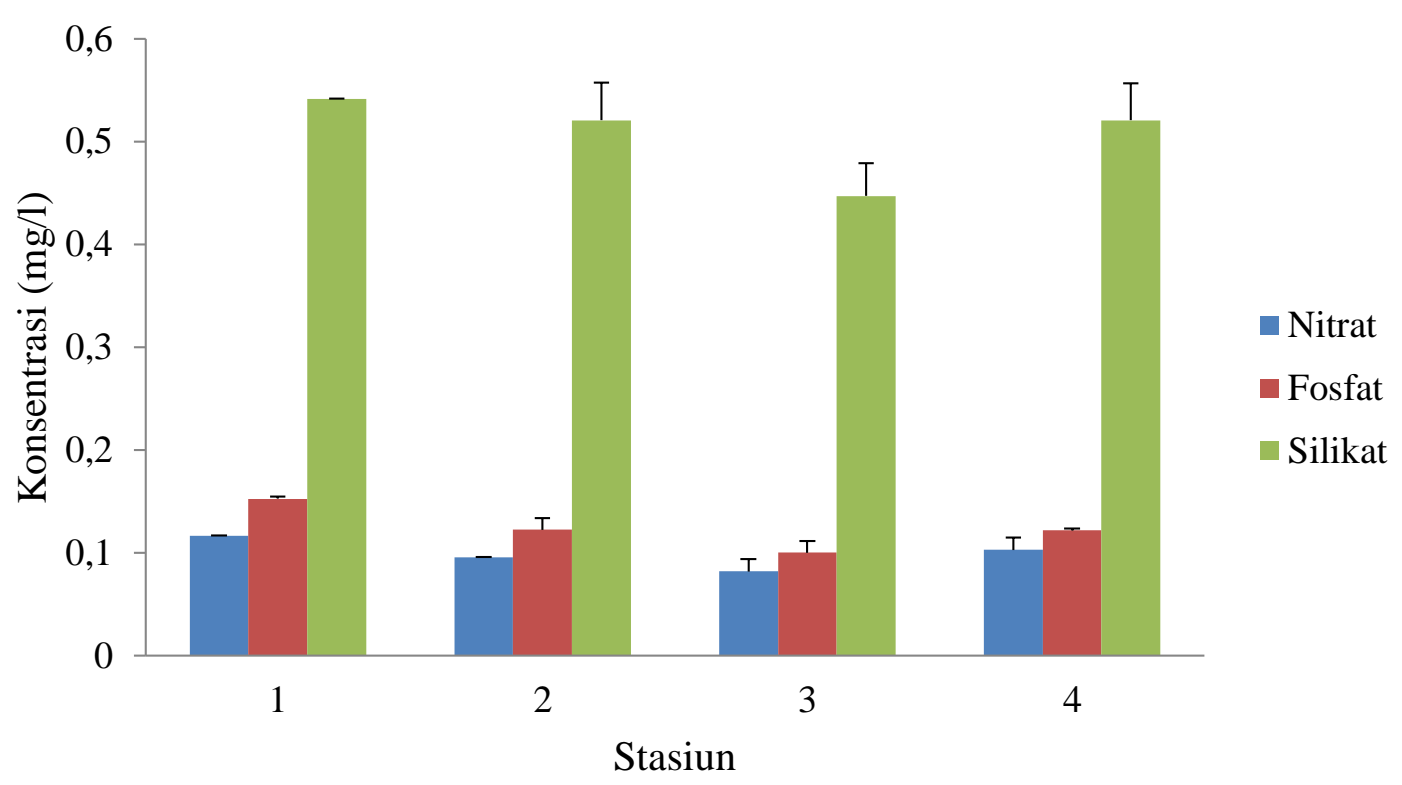

Gambar 2. Rata-rata Konsentrasi Nitrat, Fosfat dan Silikat

Berdasarkan Gambar 2diketahui bahwa konsentrasi nitrat yang paling tinggi pada stasiun 1 dengan rata-rata $0,1167 \mathrm{mg} / \mathrm{l}$, tingginya konsentrasi nitrat di stasiun ini dibandingkan dengan stasiun lainnya dikarenakan stasiun ini berada di daerah pemukiman masyarakat dan berada dekat dengan pantai. Aktivitas di daerah ini terdiri dari buangan limbah rumah tangga serta aktivitas manusia dari daratan. Berbagai aktivitas tersebut akan menghasilkan bahan organik yang hanyut bersamaan dengan arus menuju perairan pantai. Amstrong dalam Amin (2017) menyatakan bahwa kadar nitrat di perairan dekat pantai cenderung tinggi akibat adanya tambahan dari daratan melalui sungai-sungai. Sebagaimana pernyataan Saribu et al. (2017) menambahkan bahwa perbedaan kandungan nitrat dari pemukiman hingga laut lepas pantai mengalami penurunan disebabkan karena perbedaan kuantitas buangan limbah di lingkungan masing-masing stasiun, sedangkan konsentrasi nitrat terendah terdapat pada stasiun 3 dengan rata-rata $0,0819 \mathrm{mg} / \mathrm{l}$, rendahnya konsentrasi nitrat di stasiun ini diduga karena stasiun ini berada jauh dari aktivitas masyarakat. Makmur et al. (2012), dikatakan bahwa distribusi nitrat antara muara dengan laut lepas diperoleh bahwa nitrat bervariasi dimana dekat pantai lebih tinggi dibanding lokasi jauh dari pantai.

Konsentrasi fosfat tertinggi terdapat pada stasiun 1 dengan nilai $0,1526 \mathrm{mg} / \mathrm{l}$, tingginya konsentrasi fosfat diduga karena mendapatkan aliran unsur hara dari daratan atau endapan dari daratan saat terjadi hujan, dan juga dari hasil kegiatan anthropogenik lainnya. Hal ini sesuai dengan pernyataan Patty et al. (2015) menyatakan bahwa sumber utama fosfar adalah dari pelapukan batuan, endapan terestrial yang mengalami erosi dan dibawa oleh aliran sungai menuju ke muara sehingga mempengaruhi keberadaan fosfat di perairan laut, sedangkan konsentrasi fosfat terendah terdapat pada stasiun 3 dengan nilai $0,1002 \mathrm{mg} / \mathrm{l}$, rendahnya konsentrasi fosfat pada stasiun ini karena daerah tersebut jauh dari daratan, selain itu kemungkinan disebabkan oleh kedalaman perairan pada stasiun yang dalam dan 
kaitannya dengan proses pengambilan sampel air pada kedalaman $30 \mathrm{~cm}$ dibawah permukaan menyebabkan konsentrasi fosfat pada stasiun ini rendah. Sesuai pernyataan Muchtar dan Simanjuntak (2008) bahwa rendahnya konsentrasi fosfat pada perairan dipengaruhi oleh kedalaman, secara alami fosfat terdistribusi mulai dari permukaan sampai dasar.

Konsentrasi silikat tertinggi terdapat pada stasiun 1 dengan nilai 0,5418 mg/l, Tingginya konsentrasi silikat dikarenakan adanya aktivitas masyarakat dan aktivitas alami dari perairan itu sendiri. Menurut Simanjuntak (2012), sumber utama kandungan silikat dalam suatu perairan banyak dipengaruhi proses erosi serta curah hujan. Nutrien silikat diperlukan dan berpengaruh terhadap proses pertumbuhan dan perkembangan hidup beberapa jenis fitoplankton diantaranya diatom untuk pembentukan kerangka dinding selnya, sedangkan konsentrasi silikat terendah terdapat pada stasiun3 dengan nilai $0,4447 \mathrm{mg} / \mathrm{l}$, Konsentrasi silikat terendah terdapat di stasiun 3 dengan nilai $0,4447 \mathrm{mg} / \mathrm{l}$, rendahnya konsentrasi silikat pada stasiun ini diduga karena stasiun ini jauh dari daratan dan langsung berhadapan dengan laut terbuka. Hal ini sesuai dengan pendapat Risamasu (2011), yang menyatakan distribusi silikat di perairan pesisir umumnya lebih tinggi dari pada di laut terbuka karena limpasan sungai.

\section{Jenis dan Kelimpahan Diatom}

Jenis diatom yang ditemukan di perairan Tanjung Tiram Kabupaten Batu Bara Sumatera Utara dapat dilihat pada Tabel 2.

Tabel 2. Komposisi Diatom Pada Setiap Stasiun

\begin{tabular}{clcccc}
\hline No & Spesies & \multicolumn{5}{c}{ Stasiun } \\
\cline { 2 - 6 } & & I & II & III & IV \\
\hline 1 & Thallassiosira sp & + & + & + & + \\
2 & Cossinodiscus $\mathrm{sp}$ & + & + & + & + \\
3 & Pleurosigma $\mathrm{sp}$ & + & + & + & + \\
4 & Thallassionema $\mathrm{sp}$ & - & + & + & - \\
5 & Tabellaria $\mathrm{sp}$ & + & - & + & - \\
6 & Navicula $\mathrm{sp}$ & - & - & + & - \\
7 & Odontella $\mathrm{sp}$ & - & + & + & - \\
8 & Chaetoceros $\mathrm{sp}$ & - & + & + & - \\
9 & Amphora $\mathrm{sp}$ & - & - & + & - \\
10 & Aulacoseira $\mathrm{sp}$ & + & + & + & + \\
11 & Fragilaria $\mathrm{sp}$ & - & + & + & + \\
12 & Gomphonema $\mathrm{sp}$ & + & + & - & - \\
\hline & Jumlah & 6 & 9 & 11 & 5 \\
\hline
\end{tabular}

Pada Tabel 2 dapat dilihat spesies diatom yang paling banyak ditemukan terdapat pada stasiun 3 dengan jumlah 11 spesies, dan paling sedikit ditemukan di stasiun 4 dengan jumlah 5 spesies. Adapun spesies yang paling mendominan di semua stasiun yaitu: Cossinodiscus sp., Aulacoseira sp., Thallasiosira sp dan Pleurosigma sp. Kelimpahan diatom pada perairan Tanjung Tiram berdasarkan stasiun memiliki nilai bervariasi tetapi tidak begitu jauh dan dapat dilihat pada Tabel 
Tabel 3. Kelimpahan Diatom PadaSetiapStasiunPenelitian

\begin{tabular}{ccc}
\hline Stasiun & Kelimpahan Diatom (ind/I) & Rata-rata Kelimpahan Diatom \pm St. Dev \\
\hline \multirow{2}{*}{1} & 193,7 & $156,9 \pm 38$ \\
& 116,7 & \\
2 & 160,4 & $302,8 \pm 105$ \\
& 310,4 & \\
& 193,7 & $247,9 \pm 40$ \\
3 & 404,2 & \\
& 239,6 & \\
& 291,7 & $251,4 \pm 11$ \\
4 & 212,5 & \\
\end{tabular}

Berdasarkan Tabel 3 terlihat bahwa rata-rata kelimpahan diatom pada masingmasing stasiun bervariasi. Nilai rata-rata kelimpahan diatom yang ditemukan setiap stasiun di perairan Tanjung Tiram berkisar antara 156,9 - 302,8 ind/l dengan rata-rata kelimpahan tertinggi ditemukan di stasiun 2 yaitu $302,8 \mathrm{ind} / \mathrm{l}$, tingginya kelimpahan diatom pada stasiun 2 dari pada stasiun lainnya diduga adanya pemasukan bahan organik dari daratan yang berasal dari kegiatan pelabuhan yang dibuang secara langsung ke perairan seperti: sisa-sisa makanan dan beberapa organisme yang mati yang kemudian terurai, hal ini sesuai dengan pendapat Nengsi et al. (2015), menyatakan kelimpahan diatom pada suatu perairan disebabkan oleh pemasukan bahan organik dari daratan dan tidak terjadi secara terus menerus sehingga menjadikan perairan yang kaya akan kelimpahan diatom. Sedangkan kelimpahan diatom terendah terdapat pada stasiun 1 dengan rata-rata kelimpahan 156,9 ind/l, rendahnya kelimpahan diatom pada stasiun ini diduga berkaitan erat dengan kondisi perairan dan kandungan oksigen terlarut yang rendah. Stasiun 1 yang berada pada pemukiman warga dan mendapatkan pemasukan limbah dari aktivitas antropogenik, sehingga meningkatkan aktivitas bakteri untuk proses penguraian. Hal ini sesuai dengan pernyataan Simanjuntak (2012) yang menyatakan bahwa, oksigen terlarut merupakan salah satu penunjang utama kehidupan di laut dan indikator kesuburan perairan, kadar oksigen terlarut semangkin menurun seiring dengan semangkin meningkatnya limbah organik di perairan, hal ini disebabkan oksigen yang ada dibutuhkan oleh bakteri untuk menguraikan zat organik menjadi zat anorgnaik.

\section{Hubungan Kelimpahan Diatom dengan Konsentrasi Nitrat, Fosfat dan Silikat di Perairan Tanjung Tiram}

Berdasarkan hasil analisis regresi linier berganda didapat nilai kefisien korelasi (R) dengan nilai 0,544 menunjukkan bahwa hubungan antara konsentrasi nitrat, fosfat dan silikat pada diatom adalah sedang. Kemudian nilai $\mathrm{R}$ square (R2) bernilai 0,296 artinya persentasi sumbangan dari variabel nitrat, fosfat dan silikat terhadap diatom adalah $29,6 \%$ dan sisanya 70,4\% dipengaruhi oleh faktor lain. Selanjutnya diperoleh persamaan regresi linier sebagai berikut:

$\mathrm{Y}=350,906-58,065_{\mathrm{N}}-2644,624_{\mathrm{F}}+$ $440,363_{S}$ 
Hasil analisis regresi tersebut memperlihatkan bahwa zat hara yang memiliki hubungan searah (berbanding lurus) adalah silikat. Sedangkan zat hara yang memiliki hubungan berbanding terbalik yaitu: nitrat dan fosfat.

Hubungan antara kelimpahan daitom dengan konsentrasi nitrat memiliki nilai negatif, dengan nilai koefisien $=$ 58,065 dengan nilai koefisien determinasi $\left(\mathrm{R}^{2}\right)=0,296$ dan koefisien korelasi $\mathrm{r}=$ 0,544. Nitrat memberikan pengaruh terhadap kelimpahan diatom sebesar $0,5807 \%$ dengan nilai negatif, yang mana semakin tinggi konsentrasi nitrat, maka kelimpahan diatom di perairan Tanjung Tiram akan menurun.Hal ini sesuai dengan pernyataan Permatasari et al. (2016) yang menyatakan, nitrat (NO3-) merupakan zat hara utama yang di butuhkan oleh diatom untuk tumbuh dan berkembang dengan baik, besarnya konsentrasi nitrat yang ada pada perairan akan merangsang pertumbuhan bagi diatom, karena konsentrasi nitrat pada konsentrasi tertentu dapat memberikan kondisi pertumbuhan baik bagi diatom dan dapat menjadi racun di perairan apabila konsentrasi melebihi yang dibutuhkan.

Hubungan antara kelimpahan diatom dengan konsentrasi fosfat memiliki nilai negatif dengan nilai koefisien = 2644,624 dengan nilai koefisien determinasi $\left(\mathrm{R}^{2}\right)=0,296$ dan koefisien korelasi $r=0,544$. Fosfat memberikan pengaruh terhadap kelimpahan diatom sebesar - 26,66\% dengan nilai negatif, yang mana semakin tinggi konsentrasi fosfat maka kelimpahan diatom di perairan Tanjung Tiram akan menurun. Hal ini sesuai dengan pernyataan Hasrun et al. (2013) bahwa tingginya konsentrasi fosfat disebabkan pemanfaatan fosfat oleh diatom kurang optimal yang dapat dilihat dengan rendahnya kelimpahan diatom.
Hubungan antara kelimpahan diatom dengan konsentrasi silikat memiliki nilai positif dengan nilai koefisien $=$ 440,363 dengan nilai koefisien determinasi $\left(\mathrm{R}^{2}\right)=0,296$ dan koefisien korelasi $\mathrm{r}=$ 0,544. Silikat memberikan pengaruh terhadap kelimpahan diatom sebesar $4,403 \%$ dengan nilai positif, yang mana setiap kenaikan konsentrasi silikat, akan diikuti dengan kenaikan kelimpahan diatom di perairan Tanjung Tiram. Hal ini sesuai dengan pernyataan Lukman et al. (2014) yaitu silikat terlarut di perairan pesisir dan laut berperan penting dalam pertumbuhan fitoplankton seperti diatom, ditambah lagi dengan pernyataan Padang (2013) yaitu diatom mempunyai dinding sel yang terdiri dari dua bagian (frustual) yang terbuat dari silikat, karena itu silikat sangat mempengaruhi perumbuhan dan perkembangan populasi diatom.

\section{KESIMPULAN DAN SARAN}

Kualitas perairan Tanjung Tiram ditinjau dari faktor fisika dan kimia (suhu, $\mathrm{pH}$, kecepatan arus, dan salinitas) masih tergolong baik dan layak untuk mendukung kehidupan diatom, sedangkan untuk oksigen terlarut dan kecerahan masih belum mendukung kehidupan diatom di perairan. Konsentrasi nitrat berkisar antara $0,0819-0,1167 \mathrm{mg} / \mathrm{l}$, konsentrasi fosfat berkisar antara $0,1002-0,1549 \mathrm{mg} / \mathrm{l}$ dan konsentrasi silikat $0,4447-0,5418 \mathrm{mg} / \mathrm{l}$. Kelimpahan diatom dari masing-masing stasiun berkisar antara 156,9 - 302,8 ind/l.

Hubungan kelimpahan diatom dengan konsentrasi nitrat memiliki hubungan sedang dan negatif dengan nilai koefisien $=-58,065$, yang mana semakin tinggi konsentrasi nitrat maka kelimpahan diatom akan menurun. Hubungan kelimpahan diatom dengan konsentrasi fosfat memiliki hubungan sedang dan negatif dengan nilai koefisien $=-2644,624$, yang mana semakin tinggi konsentrasi fosfat maka kelimpahan diatom akan 
menurun. Hubungan kelimpahan diatom dengan konsentrasi silikat memiliki hubungan sedang dan positif dengan nilai koefisien $=440,363$, yang mana semakin tinggi konsentrasi silikat diikuti dengan kenaikan kelimpahan diatom.

Perlu dilakukan penelitian lanjutan tentang kandungan logam berat pada kerang bulu di Perairan Tanjung Tiram, di karenakan banyaknya kegiatan nelayan yang mencari kerang di sekitar perairan Tanjung Tiram yang masing terdapat pengaruh limbah dari pemukiman masyarakat dan sekitarnya dan diharapkan hasil penelitian ini dapat dijadikan salah satu rujukan oleh pihak Pemerintah Kecmatan Tanjung Tiram dalam memantau beban masukan baik yang berasal dari aktivitas manusia (unsur zat hara).

\section{UCAPAN TERIMA KASIH}

Pada kesempatan ini penulis menyampaikan ungkapan terima kasih kepada Didik Riyubas S.H., Nur Arifin, S.Pi., Mestika Yunas, A.Md.,Helvitri, S.Farm. Ungkapan terima kasih kepada Ayahanda dan Ibunda tercinta yang telah memberikan do'a, dukungan moral dan material. Tidak lupa kepada teman-teman IK014 atas kerja sama dan motivasinya dan kepeduliannya selama ini serta semua pihak yang telah membantu baik yang secara langsung dan tidak langsung dalam pelaksanaan penelitian ini yang tidak dapat penulis sebutkan namanya satu persatu 


\section{DAFTAR PUSTAKA}

1. Amin. M., S. Nedi, dan I. Nurrachmi. 2017. Analisis Tingkat Kesuburan Perairan Muara Sungai Mesjid Kota Dumai Ditinjau Dari Nitrat, Fosfat dan Kelimpahan Diatom. Jurnal Online Mahasiswa. Universitas Riau. Pekanbaru.

2. Amstrong, Y. 1995. Distribusi kandungan Fosfat dan Nitrat Pada Pasang dan Surut di Perairan Muara Angkek Teluk Jakarta.Skripsi. Fakultas Perikanan Universitas Riau. Pekanbaru.74 hal (tidak diterbitkan).

3. Badan Pusat Statistika Kabupaten Batu bara. Lima puluh 2017. Batu Bara Dalam Angka 2017.

4. Fachrul, M. F. 2007. Metode Sampling Bioekologi. Bumi Aksara, Jakarta. 198 hal.

5. Hasrun, L., K. Ma'ruf dan Salwiyah. 2013.Studi Biodiversitas Diatom Bentik pada Areal Mangrove di Perairan Kecamatan Kolono Kabupaten Konawe Selatan. Jurnal Mina Laut Indonesia 02 (06): 35-47.

6. Hidayat, R., L. Viruly dan D. Azizah. 2013. Kajian Kandungan Klorofil-a pada Fitoplankton Terhadap Parameter Kualitas Air di Teluk Tanjung Pinang Kepulauan Riau. Universitas Maritim Raja Ali Haji. KEPRI.

7. Lukman, M., A. Nasir, K. Amri, R, Tambaru, M. Hatta, Nurfadilla, dan R. J. Noer. 2014. Silikat Terlarut di Perairan Pesisir Sulawesi Selatan. Jurnal Ilmu dan Teknologi Kelautan 6(2): 461-478.

8. Makmur, M., H. Kusnoputranto., S. S. Moersidik., D. S. Wisnubroto. 2012. Pengaruh Limbah Organik dan Rasio N/P Terhadap Kelimpahan Fitoplankton di Kawasan Budidaya Kerang Hijau Cilincing. Jurnal Telnologi Pengolahan Limbah 15(2): 51-61.

9. Nengsi, N. W., I. Nurrachmi dan Thamrin. 2015. Hubungan Antara Konsentrasi Nitrat, Fosfat dan Silikat Terhadap Kelimpahan Diatom di Sekitar Perairan Tapian Nauli. Jurnal Online mahasiswa. Universitas Riau. Pekanbaru

10. Nontji, A. 2008. Plankton Laut. LIPI Press. Jakarta. 331 hal.

11. Padang, A. 2012. Peran Diatom Bagi Produktivitas Primer di Lingkungan Bentik. Jurnal Bimafika (4): 420-424.

12. Patty, I. S. 2013. Kadar Nitrat dan Oksigen Terlarut di Perairan Pulau Talise Sulawesi Utara. Jurnal Ilmia Platax 1(4): 167-176.

13. Permatasari, R, D., Djuwito dan Irwani. 2016. Pengaruh Kandungan Nitrat dan Fosfat Terhadap Kelimpahan Diatom di Muara Sungai Wulan. Journal Of Maquares 5(4): 224232.

14. Risamasu, J. F dan H. B. Prayitno. 2011. Kajian Zat Hara Fosfat, Nitrit, Nitrat dan Silikat di Perairan Kepulauan Matasiri, Kalimantan Selatan. 16(3): 135- 142.

15. Saribu, M. D., A. Mulyadi, dan I. Nurrachmi. 2017. Studi Kelimpahan Diatom (Baccilariophyta) Planktonik Dengan Konsentrasi Nitrat dan Fosfat di Perairan Belawan Provinsi Sumatera Utara. Jurnal Online Mahasiswa. Universitas Riau. Pekanbaru.

16. Simanjuntak, M. 2008. Kualitas Air Laut ditinjau Dari Aspek Zat Hara, Oksigen Terlarut dan $\mathrm{pH}$ di Perairan Banggai, Sulawesi Tengah. Jurnal Ilmu dan Teknologi Kelautan Tropis 4 (2): 290-303 